\title{
New faunistic data for the Sicilian Aracnofauna (Arachnida Araneae)
}

\author{
Antonino Dentici \& Franco Ciro Amata \\ 1Via Enrico Cialdini 2, 90124 Palermo, Italy; e-mail: a.dentici@virgilio.it \\ 2Piazza S.Antonino 1, 94018 Troina (Enna), Italy; e-mail: amata.francociro@gmail.com
}

\begin{abstract}
New spiders (Arachnida Araneae) from Sicily (Italy) are reported in this paper. Particularly, one familia, eight genera, and thirteen new species are examined. Additional biological and taxonomic notes are also provided.
\end{abstract}

KEY WORDS Araneae; new data; first records; Sicily.

Received 11.08.2018; accepted 20.09.2018; printed 30.09.2018; published online 05.10.2018

\section{INTRODUCTION}

In the first article of one of the two authors (Dentici, 2017), two new species were presented for Sicily and the number of those known for Sicily rose to 405. To date, the World Spider Catalog (2018), after only one year, reports 418 known spiders.

During the sampling of the authors on the territory, which took place between the end of 2017 and half of 2018 and it is not distributed in a homogeneous way, some novelties have been found in Sicily. In fact, this work reports 1 familia, 7 genera, and 13 new species for Sicily, raising the number of spiders known to 431 species divided into 194 generates and 44 families.

These data are helping and encourage us to continue our research on our territory, sure that new data yet to be discovered are many on the Sicilian aracnofauna.

\section{MATERIAL AND METHODS}

All samples were collected on sight on plants, under the rocks or in their web. Some samples were photographed in nature with a Canon EOS 7D Mark II with a EF100mm Macro with $20 \mathrm{~mm}$ extension rings and 1.4 canon multiplier (F.C. Amata).

All the samples, taken in laboratory, were treated with ethyl acetate, observed with binoculars and photographed with a Nikon d90 reflex and a macro lens of $100 \mathrm{~mm}$ for identification by Dentici Antonino. The specimens were stored in centrifuge tubes of different sizes, depending on the size of the sample, and were fixed in $75 \%$ ethanol.

The samples are stored in the collection of one author (A. Dentici) and the "legit" is indicated for each sample. Each locality and / or collection site is in the original language (Italian).

The classification, taxonomic order, nomenclatural arrangement, and presence in the Sicilian territory follow Roberts (1995), Trotta (2004), Pantini \& Isaia (2018), and World Spider Catalog (2018). Other sources have also been used for the correct identification and are, when used, signed in the species remarks.

For each species literature, chorotype and distribution are indicated. 


\section{RESULTS}

\section{Systematics}

Ordo ARANEAE Clerck, 1757

Familia ARANEIDAE Clerck, 1757

Genus Nuctenea Simon, 1864

\section{Nuctenea umbratica (Clerck, 1757)}

EXAMINED MATERIal. Sicily (Italy), Troina (Enna), 3749’49.1”N 14³4’08.2” E, 20.I.2018, 1 female, legit F.C. Amata.

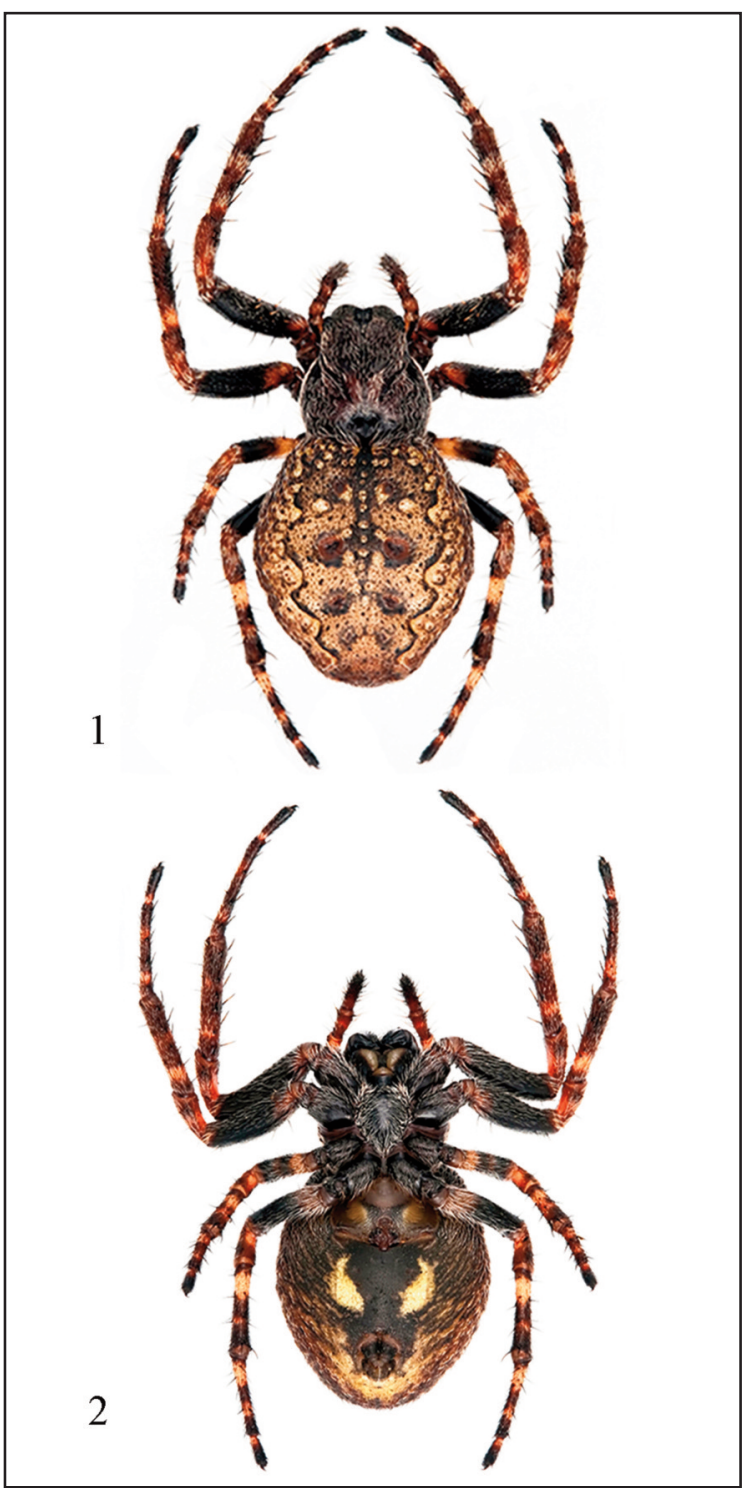

Figures 1, 2. Nuctenea umbratica female dorsal (Fig. 1) and ventral (Fig. 2) view (photos by F.C. Amata).
Distribution. Europe to Azerbaijan.

REMARKS. New genus and new species for Sicily. The sample was found on its web, built in a beechwood near the lake Ancipa, which occupied the center, during the evening hours.

Familia AMAUROBIIDAE Thorell, 1870

Genus Amaurobius C.L. Koch, 1837

Amaurobius erberi (Keyserling, 1863)

EXAMINED MATERIAL. Sicily (Italy), Troina (Enna), 37³2'05.3” N 14 ${ }^{\circ} 51^{\prime} 57.5^{\prime \prime}$ E, 20.I.2018, 1 female and 1 male, legit F.C. Amata.

Distribution. Europe, Canary Islands.

REMARKs. New species for Sicily. The samples were found under a rock in a rural area, bordered by a highway. Other specimens have been studied, in the same period, in Palermo and province, attributable to the species of $A$. erberi, but immature to give a certain identification.

Familia GNAPHOSIDAE Pocock, 1898

Genus Sethaphis Simon, 1893

Setaphis parvula (Lucas, 1846)

Examined Material. Sicily (Italy), Palermo, Monreale: Caculla, $38^{\circ} 03^{\prime} 01.3^{\prime \prime} \mathrm{N} 13^{\circ} 14^{\prime} 42.2^{\prime \prime} \mathrm{E}$, 02.VI.2018, 1 male, legit A. Dentici.

DistriBUTION. Mediterranean.

REMARKS. New genus and new species for Sicily. The sample was found while wandering on a dirt road, near Sant'Elia River, at night.

This species is present on Italian territory only in Sardinia (Pantini et al., 2013) and now also in Sicily.

Familia LYCOSIDAE Sundevall, 1833

Genus Aulonia C.L. Kock, 1847

Aulonia albimana (Walckenaer,1805)

EXAmined Material. Sicily (Italy), Palermo, 26.III.2018, 1 male and 1 female, legit A. Dentici. 
DistRibution. Europe, Turkey, Caucasus, Russia to Turkmenistan.

Remarks. New genus and new species for Sicily. Both specimens were sampled in a small green area on the outskirts of the city, in an anthropized area. The specimens were found under the foliage of some Eucalyptus trees.

Genus Trabea Simon, 1876

\section{Trabea paradoxa Simon, 1876}

Examined Material. Sicily (Italy), Troina (Enna), 15.III.2018, 1 juvenille female, legit Franco Ciro Amata; Sicily, Palermo, Monreale: Caculla, 38 03'01.3”N 13¹4'42.2”'E, 19.V.2018, 1 male, legit A. Dentici.

DistRiBUtion. Southern Europe, Turkey.

REMARKS. New genus and new species for Sicily. These two specimens were collected both during the evening hours, wandering in gardens of private homes in the countryside area.

Familia LYNIPHIIDAE Blackwall, 1859

Genus Lyniphia Latreille, 1804

\section{Lyniphia tenuipalpis Simon, 1884}

Examined material. Sicily (Italy), Palermo, Pioppo, Bosco di Casaboli, 3804'01.0”'N

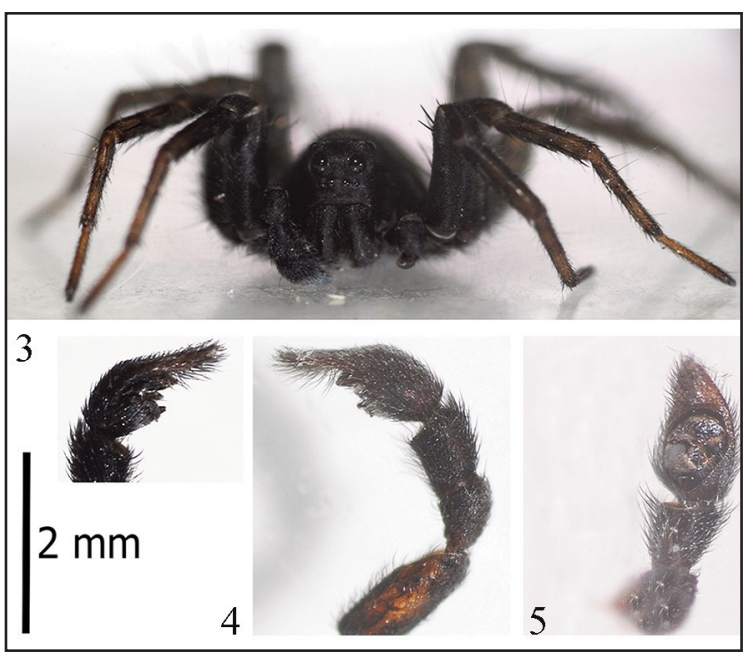

Figures 3-5. Aulonia albimana male frontal view (Fig. 3), palp lateral (Fig. 4), and frontal view (Fig. 5).
13'13'42.9'"E, 22.X.2017, 1 female, legit A. Dentici (Natural Science Museum E. Caffi of Bergamo collection).

Distribution. Europe to Central Asia, Algeria.

REMARKS. New species for Sicily. The specimen was collected on its web, built among the brambles.

Familia MITURGIDAE Simon, 1886

Genus Zora C.L. Koch, 1847

\section{Zora manicata Simon, 1878}

Examined material. Sicily (Italy), Troina (Enna), 37 48'19.8” N 14 38'47.5” E, 12.II.2018, 2 female, legit F.C. Amata.

DistRIBUTION. Europe, Israel, Iran.

REMARKs. New genus and new species for Sicily. The specimens were sampled in a tree-lined area along a state road, which runs through a rural area. They were found under rocks. The sample was identified through description of Levy (2003).

Familia SEGESTRIIDAE Simon, 1893

Genus Segestria Latreille, 1804

\section{Segestria bavarica C.L. Koch, 1843}

Examined material. Sicily (Italy), Palermo, Monte Pellegrino, 11.XI.2017, 1 female, legit A. Dentici.

Distribution. Europe to Azerbaijan.

Remarks. New species for Sicily. The sample was found exiting its tubular web, during the night. The den had been built inside a hole in a Eucalyptus.

In the same area, S. florentina (Rossi, 1790) specimens were observed. In one case, the two species were observed on the cavities of the same tree, in which the $S$. bavarica occupied the highest and $S$. florentina the lowest ones.

Familia THERIDIIDAE Sundevall, 1833 Genus Episinus Walckenaer, 1809 


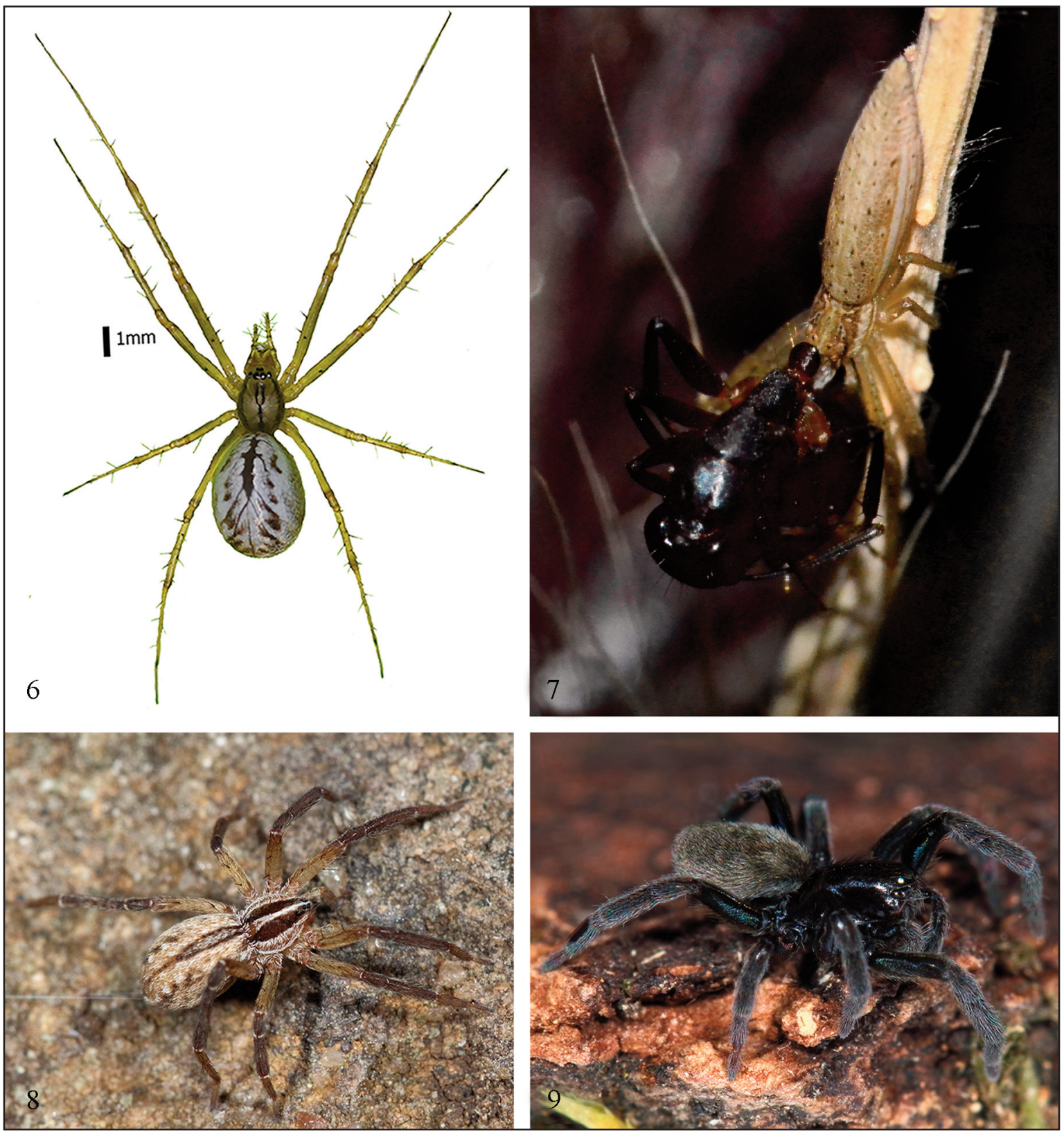

Figure 6. Lyniphia tenuipalpis female (photo by A. Dentici). Figure 7. Monaese paradoxus preying on Camponotus barbaricus Emery, 1904 (photo by A. Dentici). Figure 8. Zora manicata female (photo by F.C. Amata). Figure 9. Titanoeca tristis (photo by F.C. Amata).

\section{Episinus algiricus Lucas, 1846}

Examined material. Sicily (Italy), Palermo, Parco della Favorita, $38^{\circ} 09^{\prime} 46.0^{\prime \prime} \mathrm{N} 13^{\circ} 20^{\prime} 18.9^{\prime \prime} \mathrm{E}$, 2 female and 3 male, legit A. Dentici; Sicily (Italy), Palermo, Monte Pellegrino, 3809'51.3”N $13^{\circ} 20^{\prime} 52.3$ 'E, 24.VI.2018, 1 female, legit A. Dentici.
Distribution. Portugal, Spain, France, Italy, Northwest Africa, Malta (?).

REMARKS. The specimens were sampled on their webs, during the evening hours. The webs were built on a chain-link fence that runs along a path inside the reserve. The canvases were not far from each other. New species for Sicily. This new 
data for the Sicilian territory supports the reports about the presence of E. algiricus on the Maltese Archipelago (Dentici, 2018).

Genus Rhomphaea L.Koch,1872

\section{Rhomphaea rostrata (Simon, 1873)}

Examined material. Sicily (Italy), Palermo, Monreale: Caculla, $38^{\circ} 03^{\prime} 01.3^{\prime \prime} \mathrm{N} 13^{\circ} 14^{\prime} 42.2^{\prime \prime} \mathrm{E}$, 10.VI.2018, 1 male, legit A. Dentici.

Distribution. Canary Islands, Portugal, Spain, France, Italy, Bosnia and Herzegovina, Croatia, Greece.

REMARKS. New genus and new species for Sicily. The specimen was sampled on a lemon tree in a private garden, near Sant'Elia River, during the night.

Familia THOMISIDAE Sundevall, 1833

Genus Monaeses Thorell, 1869

Monaeses paradoxus (Lucas, 1846)

Examined Material. Sicily (Italy), Palermo, Monte Pellegrino, $38^{\circ} 08^{\prime} 56.7^{\prime \prime} \mathrm{N} 13^{\circ} 21^{\prime} 28.1^{\prime \prime} \mathrm{E}$, 16.IV.2016, 1 female, legit A. Dentici; Sicily, Palermo, Aspra, $38^{\circ} 08^{\prime} 59^{\prime \prime} \mathrm{N}$ 13029'24'E, 17.IV.2018, 1 female, legit R. Viviano.

DistRIBUTION. Europe to Iran, Africa.

REMARKS. New genus and new species for Sicily. The specimens were collected while standing on plants belonging to the Poaceae family, waiting for their prey. One of the two specimens was observed while he was preying on an ant Camponotus barbaricus Emery,1904 (Hymenoptera Formicidae).

Genus Xysticus C.L. Koch, 1835

Xysticus audax (Schrank, 1803)

EXAmined MATerial. Sicily (Italy), Catania, Mareneve (Etna), 37 $45^{\prime} 36^{\prime \prime} \mathrm{N} \quad 1^{\circ} 04^{\prime} 07^{\prime \prime} \mathrm{E}$, 26.V.2018, legit R. Viviano.

DistRibution. Europe, Turkey, Caucasus, Kazakhstan, Russia (Europe to Far East), Japan.
REMARKS. The sample was found under a rock. New species for Sicily.

Familia TITAENOCIDAE Lehtinem, 1967

Genus Titanoeca Thorell, 1870

Titanoeca tristis L. Koch, 1872

Examined Material. Sicily (Italy), Troina (Enna), 12.II.2018, 2 female, legit Franco Ciro Amata.

Distribution. Europe to Central Asia.

Remarks. New familia, new genus, and new species for Sicily. The specimens were found under rocks, in an open area, near a provincial road. Both specimens were found under the same rock.

\section{ACKNOLEDGMENTS}

A special thank is given to Paolo Pantini (Bergamo, Italy) and Ignazio Sparacio (Palermo, Italy) for their help, to Marco Capritti (Palermo, Italy), Roberto Viviano (Palermo, Italy) and Enrico Schifani (Palermo, Italy) for their friendship, to Valeria Lo Bianco (Palermo, Italy), my girlfriend, for her support and to all my family.

\section{REFERENCES}

Dentici A., 2017. Contribution to the knowledge of Sicilian spider fauna (Arachnida Araneae). Biodiversity Journal, 8: 861-864.

Dentici A., 2018. Contribution to the knowledge of the spider fauna (Arachnida Araneae) of the Maltese Archipelago. Biodiversity Journal, 9: 85-88.

Levy G., 2003. Spiders of the families Anyphaenidae, Hahniidae, Ctenidae, Zoridae, and Hersiliidae (Araneae) from Israel. Israel Journal of Zoology, 49: $1-31$.

Pantini P., Sassu A. \& Serra G., 2013. Catalogue of the spiders (Arachnida Araneae) of Sardinia. Biodiversity Journal, 4: 3-104.

Pantini P. \& Isaia M., 2018. Checklist of the Italian spiders (Version June 2018)

Roberts M.J., 1995. Spiders of britain and Northern Europe. Harper Collins, London, 383 pp. 
Trotta A., 2004. Introduzione ai Ragni italiani (Arachnida Araneae). Memorie della Società Entomologica Italiana, 83: 3-178. DOI: 10.4081/memorieSEI.2004.3
World Spider Catalog, 2018. World Spider Catalog, version 19.5. Natural History Museum Bern, online at http://wsc.nmbe.ch (15.07.2018) DOI: 10.24436/2 